\title{
How did the hydrologic cycle respond to the two-phase mystery interval?
}

\author{
Wally Broecker*, Aaron E. Putnam \\ Lamont-Doherty Earth Observatory of Columbia University, 61 Route 9W, PO Box 1000, Palisades, NY 10964-8000, USA
}

\section{A R T I C L E I N F O}

\section{Article history:}

Received 16 June 2012

Received in revised form

24 September 2012

Accepted 28 September 2012

Available online

\section{Keyword:}

Mystery interval

\begin{abstract}
A B S T R A C T
Lake Estancia's transition from a Big Dry episode during the first half of the Mystery Interval to a Big Wet episode during the second half has equivalents in records from across the planet. At the time of this transition, Chinese monsoons experienced pronounced weakening, closed-basin lakes in both the Great Basin of the western United States and in the southern Altiplano of South America underwent a major expansion, mountain glaciers in Southern Hemisphere middle latitudes had retreated, and the rates of increase of $\mathrm{CO}_{2}$ and of $\delta^{18} \mathrm{O}$ in Antarctic ice underwent a decrease. Finally, the precipitous drop in dust rain over Antarctica and the Southern Ocean terminated as did a similar drop in the ${ }^{13} \mathrm{C}$ to ${ }^{12} \mathrm{C}$ ratio in atmospheric $\mathrm{CO}_{2}$. These changes are consistent with a southward shift of the thermal equator. The cause of such a shift is thought to be an expansion of sea ice caused by a shutdown in deep water production in the northern Atlantic. This creates a dilemma because a similar southward shift is an expected consequence of the Heinrich event \#1 which initiated the Mystery Interval.
\end{abstract}

(c) 2012 Elsevier Ltd. All rights reserved.

\section{Introduction}

Allen and Anderson (2000) document the existence of a desiccation event (the Big Dry) in New Mexico's Lake Estancia. It began at the close of the LGM (about $18 \mathrm{ka}$ ) and lasted for about $2 \mathrm{ka}$. This time interval corresponds to the first half of the so-called Mystery Interval ( $\mathrm{H}-1$ stadial). It was preceded and followed by high stands of this now dry lake. The sediment deposited during the Big Dry interval is rich in gypsum and contain ostracods characteristic of salty water. By contrast, the sediments above and below are gypsum-free and contain ostracods characteristic of fresh water. The age of the Big Dry interval is constrained by numerous ${ }^{14} \mathrm{C}$ dates on ostracods (see Fig. 1).

As the changes in the Earth's hydrologic cycle appear to be globally orchestrated (Severinghaus et al., 2009; Asmerom et al., 2010; Broecker, in press), the question arises as to whether this is the case for the Big Dry to Big Wet transition. One problem is that a twofold division of the Mystery Interval doesn't seem to fit with the continuous drop in the atmosphere's ${ }^{14} \mathrm{C}$ content. As this drop is thought to represent the mixing of a ${ }^{14} \mathrm{C}$-enriched upper ocean with a ${ }^{14} \mathrm{C}$-depleted abyssal ocean, taken in isolation, the absence of a difference in the rate of ${ }^{14} \mathrm{C}$ decline between the first and second

\footnotetext{
* Corresponding author. Tel.: +1 845365 8413; fax: +1 8453658169.

E-mail address: broecker@ldeo.columbia.edu (W. Broecker).
}

half of the Mystery Interval suggests that no change in ocean circulation accompanied the Big Dry to Big Wet transition. Similarly, there is no significant early Mystery Interval to late Mystery Interval difference between the ${ }^{231} \mathrm{~Pa}$ to ${ }^{230} \mathrm{Th}$ ratio in Atlantic sediments (McManus et al., 2004) suggesting that the shutdown of deep water production in the northern Atlantic prevailed during this entire interval. This is also consistent with the constancy of the high dust rain onto Greenland during the course of the Mystery Interval. But, as outlined below, the hydrologic record appears to require a southward shift in the thermal equator at the midpoint of the Mystery Interval (see Fig. 2 for location of the records to be discussed).

This paper is an update on a previous one (Broecker et al., 2009) that focused on the extent of the Big Dry in the Great Basin and its possible cause. Much of the discussion had to do with the uncertainty in the offset between radiocarbon-based ages and those based on ${ }^{230} \mathrm{Th}$. With the publication of the highly precise calibration based on $40{ }^{14} \mathrm{C}-{ }^{230} \mathrm{Th}$ age comparisons in a Hulu Cave stalagmite spanning the Mystery Interval (Southon et al., 2011), these uncertainties have been resolved. Further, the similarity of the ${ }^{18} \mathrm{O}$ record for $\mathrm{O}_{2}$ trapped in polar ice (Severinghaus et al., 2009) with that for ${ }^{18} \mathrm{O}$ in Chinese stalagmites (Wang et al., 2001) strengthens the case for a global extent for the twofold Mystery Interval. As the Mystery Interval is thought to have been triggered by a Heinrich event, then it should have begun with a southward shift. Hence the second southward shift required by the results summarized below appears to create a dilemma. 


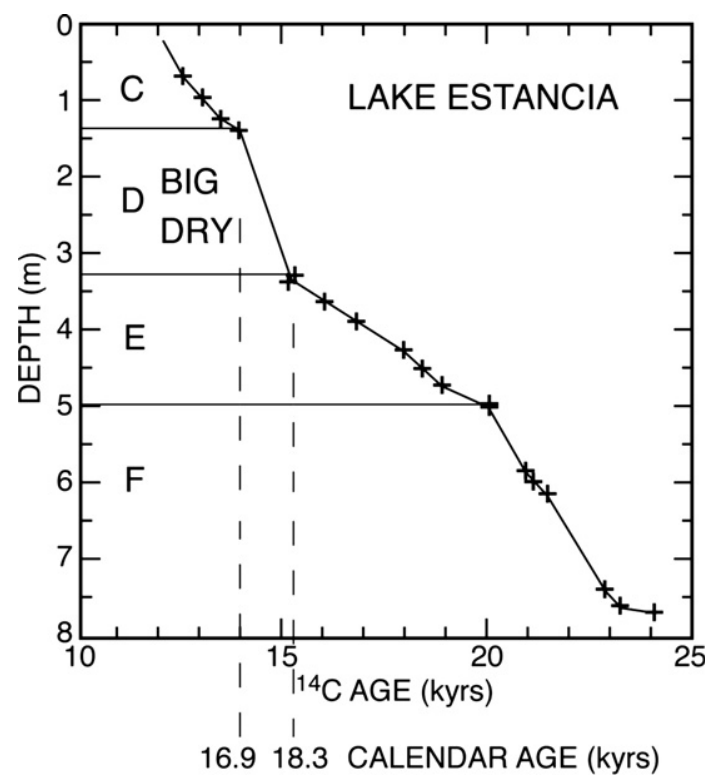

Fig. 1. Radiocarbon ages on ostracods as a function of depth in Lake Estancia's sediment (Allen and Anderson, 2000). Units F and E which were deposited during the LGM contain abundant ostracods which thrive in low salinity environments. Unit D which was deposited during the Big Dry contains rare ostracods capable of survival in salty water. Unit C which was deposited during the time of Lake Lahontan's Big Wet contains abundant fresh water ostracods. The pluses are the levels at which ${ }^{14} \mathrm{C}$ ages were obtained on ostracods.

\section{Chronologies}

Critical to this evaluation is a precise and accurate chronology. As many of the ages used here are based on ${ }^{14} \mathrm{C}$ measurements, it is important to correctly convert them to calendar ages. Although measurements on coral show that the ${ }^{230} \mathrm{Th}-{ }^{14} \mathrm{C}$ age offset decreased from about $3 \mathrm{ka}$ at the onset of the Mystery Interval to about $2 \mathrm{ka}$ at its end, there are few coral measurements which document the course of this decline. Fortunately, a new record obtained through cooperation between the Irvine group $\left({ }^{14} \mathrm{C}\right.$ measurements) and the Minnesota group ( ${ }^{230} \mathrm{Th}$ measurements) has remedied this situation (Southon et al., 2011). This remedy is based on a very detailed ${ }^{14} \mathrm{C}-{ }^{230} \mathrm{Th}$ age comparisons on samples from China's Hulu Cave. Forty such comparisons show that the ${ }^{230} \mathrm{Th}-{ }^{14} \mathrm{C}$ age difference underwent a linear decline from 3.25 ka to 2.25 ka during the course of the Mystery Interval (see Fig. 3).

Key to our arguments are radiocarbon ages on calcites precipitated in closed basin lakes. Such ages are subject to reservoir corrections. As discussed below, it is tempting to call on corrections ranging up to 700 years in order to align events in these lakes with those recorded in ice cores and stalagmites. However, unless the lakes had extremely high alkalinities such corrections are unreasonably large. The argument is as follows. As shown by Wanninkhof et al. (1985), the preindustrial invasion rate of $\mathrm{CO}_{2}$ into these lakes is on the order of $8 \mathrm{~mol} / \mathrm{m}^{2} \mathrm{yr}$. Taking into account the somewhat lower atmospheric $\mathrm{CO}_{2}$ content during the deglacial time interval, the rate would have been closer to $6 \mathrm{~mol} / \mathrm{m}^{2} \mathrm{yr}$. In order to achieve a reservoir correction on the order of 500 years would require a water column $\sum \mathrm{CO}_{2}$ inventory of 3000 moles per $\mathrm{m}^{2}$. This is about one half that for the ocean. The only lake we know of with this high a water column inventory is Mono Lake in California. Pyramid Lake, one of the remnants of Lahontan, has a current inventory on the order of 1000 moles $/ \mathrm{m}^{2}$ (i.e., a turnover time of 170 years). Indeed, this is the magnitude of the correction obtained by Broecker and Walton (1959) based on ${ }^{14} \mathrm{C}$ measurements on lake and river water. For lakes like Mono and Pyramid, the input of ${ }^{14} \mathrm{C}$ free $\mathrm{CO}_{2}$ from hot springs increases the reservoir correction but, as such contributions are difficult to quantify, it is not possible to say what it was during the Mystery Interval. In any case, the reservoir corrections are unlikely to explain the range in radiocarbon ages to be discussed in the following sections.

Another consideration is contamination with secondary ${ }^{14} \mathrm{C}$. The limited number of acid leaching experiments conducted on $\mathrm{CaCO}_{3}$ from limnic sediments show that the ${ }^{14} \mathrm{C}$ ages often increase with progressive mass loss. In order to evaluate the importance of secondary ${ }^{14} \mathrm{C}$ will require a new round of measurements.

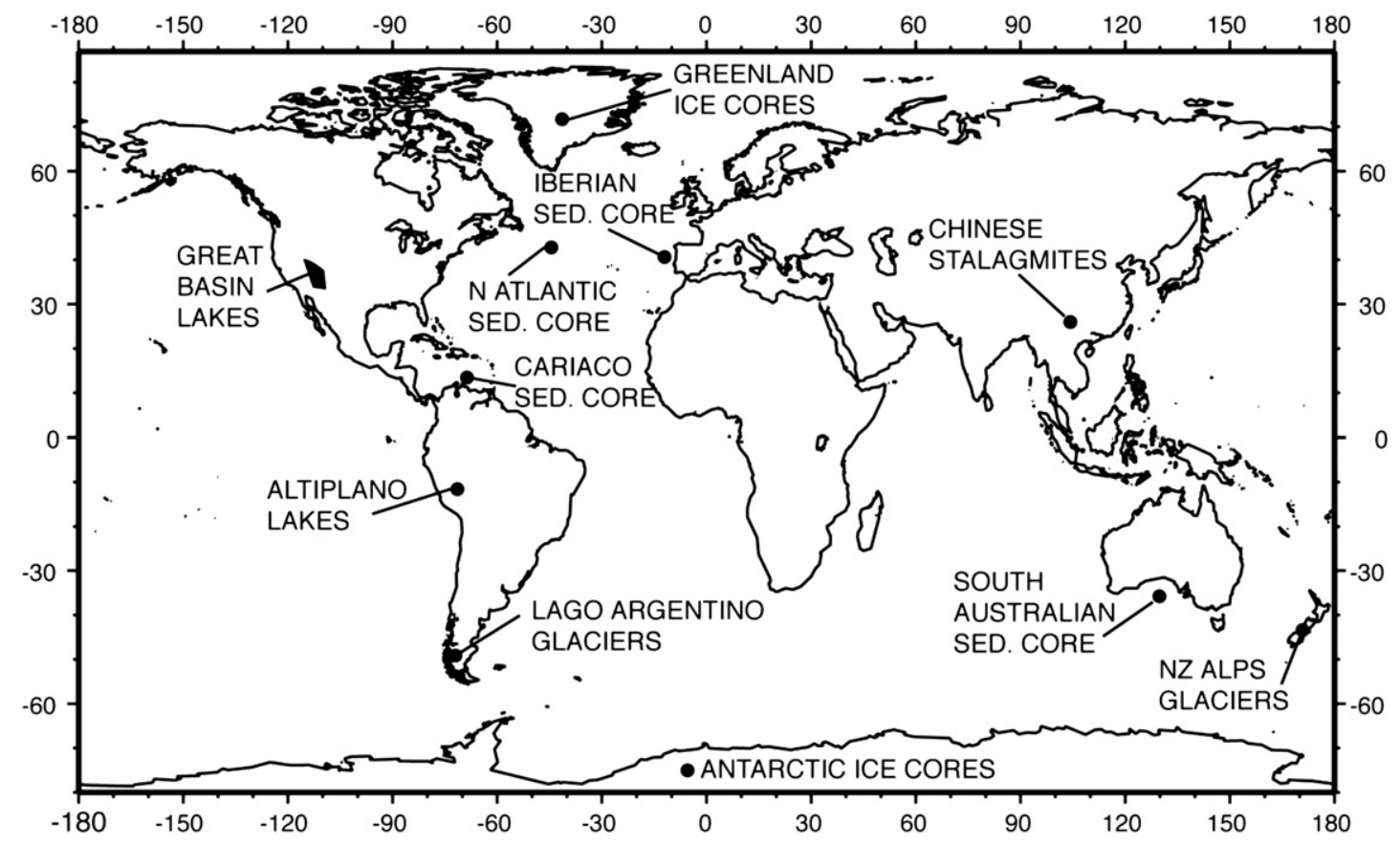

Fig. 2. Map showing the locations of the records on which this paper is based. 


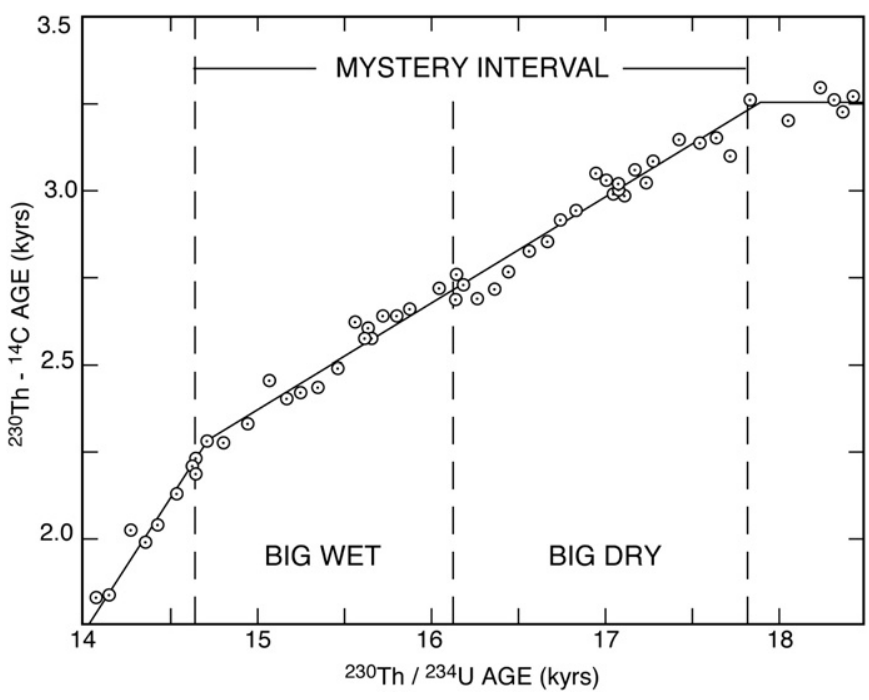

Fig. 3. Plot of the differences between the ${ }^{230} \mathrm{Th} /{ }^{234} \mathrm{U}$ age and the ${ }^{14} \mathrm{C}$ age as a function of calendar age for Mystery Interval samples from Hulu Cave (Southon et al., 2011).

Still another consideration involves dating of small entities such as ostracods. As they are easily reworked, it is possible that the radiocarbon ages for Estancia are too old.

Finally, the time intervals for the high stands of Nevada's Lake Lahontan and the Altiplano's Lake Tauca are constrained by the range in tufa ages rather than stratigraphically. Scatter related to the measurement error and variations in the extent of secondary ${ }^{14} \mathrm{C}$ uptake tend to widen the apparent duration of these high stands.

\section{The Great Basin record}

It is clear that in the western U.S.'s Great Basin the second part of the Mystery Interval was the wettest in the last $30 \mathrm{ka}$. Not only did Lake Lahontan achieve its largest size but the Great Basin's interior lakes located between Lakes Lahontan and Bonneville did as well. Although no low-elevation shorelines with Big Dry ages have been documented in any of these basins, their absence of any shoreline dates in this time interval suggests that, like Estancia, the lakes were much smaller.

\subsection{Lahontan}

As summarized in Fig. 4, 25 radiocarbon ages on tufa from the highest Lahontan shoreline (1300-1325 m) fall into that age range $12.3-13.8{ }^{14} \mathrm{C}$ ka (14.4-16.5 calendar ka). Its LGM size is documented by 20 radiocarbon ages from an intermediate stand $(1225-1250 \mathrm{~m})$. They fall in the age range $15-20{ }^{14} \mathrm{C}$ ka $(18-23$ calendar $\mathrm{ka}$ ). None of the radiocarbon measurements fall within the Big Dry 16.5-18.0 calendar ka range. Although this is consistent with the existence of a low lake stand during the first half of the Mystery Interval, in absence of any direct documentation, the size of the lake at that time remains unconstrained. Unfortunately, no datable sedimentary sections comparable to those exposed in the Estancia basin have been found in Lahontan's basin.

\subsection{Interior playas}

Several of the playas in the interior of the Great Basin have high shorelines yielding radiocarbon ages falling within the bounds of the second half of the Mystery Interval (see Table 1).

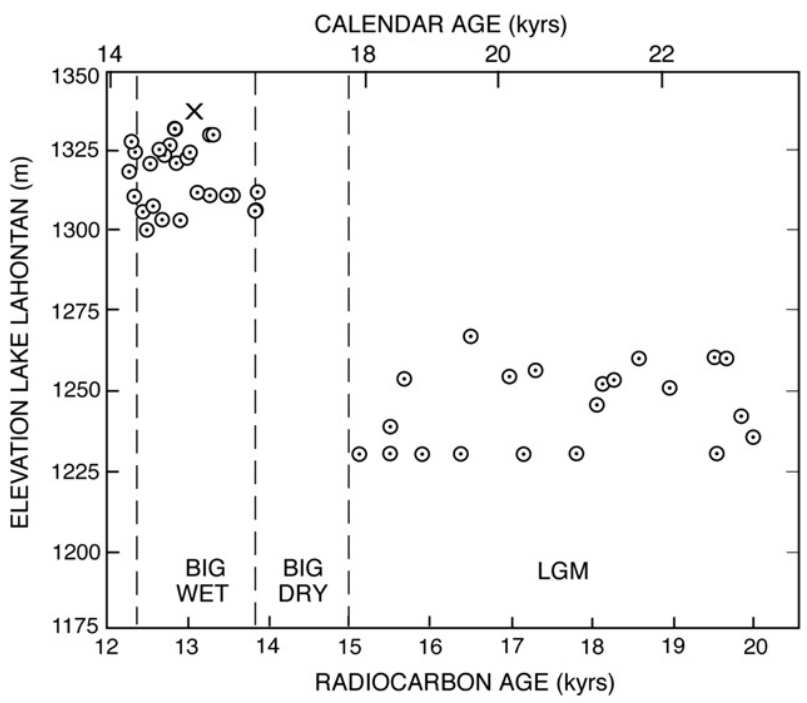

Fig. 4. Summary by Benson et al. (1990) of radiocarbon ages for tufas from Lake Lahontan's raised shorelines (open circles). The $x$ is for collagen isolated from a camel bone (Adams and Wesnousky, 1998). Note that none of these ages fall within the 1618 ka calendar age range.

Unlike Lahontan, which received most of its water from the high mountains which form the western boundary of the Great Basin, these lakes were fed by precipitation falling within the basin. Again, as is the case for Lahontan, there are no radiocarbondated deposits corresponding to the first half of the Mystery Interval.

\subsection{Bonneville}

The situation for Lake Bonneville is complicated by its overflow and the subsequent down-cutting of its outlet. Both occurred during the course of the Mystery Interval. As shown in Fig. 5, taken at face value, the radiocarbon dates on shore-zone $\mathrm{CaCO}_{3}$ materials suggest that the down cutting took place just prior to 17 calendar ka ago. In a recent paper, McGee et al. (2012) present highly precise ${ }^{230}$ Th ages on dense $\mathrm{CaCO}_{3}$ coatings deposited well beneath Bonneville's surface in small shore-zone caves. In Cathedral Cave, deposition of this $\mathrm{CaCO}_{3}$, while continuous during the LGM, ceased at close to $18 \mathrm{ka}$. One interpretation would be that the lake dropped below the level of Cathedral Cave at this time. If so, ten or so radiocarbon ages from the Provo level would have to be disregarded. Instead, as McGee et al. (2012) suggest, the cessation of $\mathrm{CaCO}_{3}$ deposition was instead the result of a change in the lake's chemistry. Perhaps, as a result of its overflow, it became undersaturated with respect to $\mathrm{CaCO}_{3}$. Hence there is no evidence for a Big Dry episode at Lake Bonneville. At best, one might postulate that a decrease in the intensity of overflow took place during this time interval.

Table 1

Radiocarbon ages on high shorelines of now dry lakes located near the Utah-Nevada border in the central Great Basin.

\begin{tabular}{llll}
\hline Location & $\begin{array}{l}\text { Radiocarbon } \\
\text { age }(\mathrm{ka})\end{array}$ & $\begin{array}{l}\text { Calendar } \\
\text { age }(\mathrm{ka})\end{array}$ & Reference \\
\hline Jakes Valley & 13.87 & 16.7 & $\begin{array}{l}\text { Garcia and } \\
\text { Stokes (2006) }\end{array}$ \\
Newark Valley & 13.78 & 16.6 & Redwine (2003) \\
Diamond Valley & 13.50 & 16.3 & Tackman (1993) \\
Franklin Valley & 13.33 & 16.0 & Lillquist (1994) \\
\hline
\end{tabular}




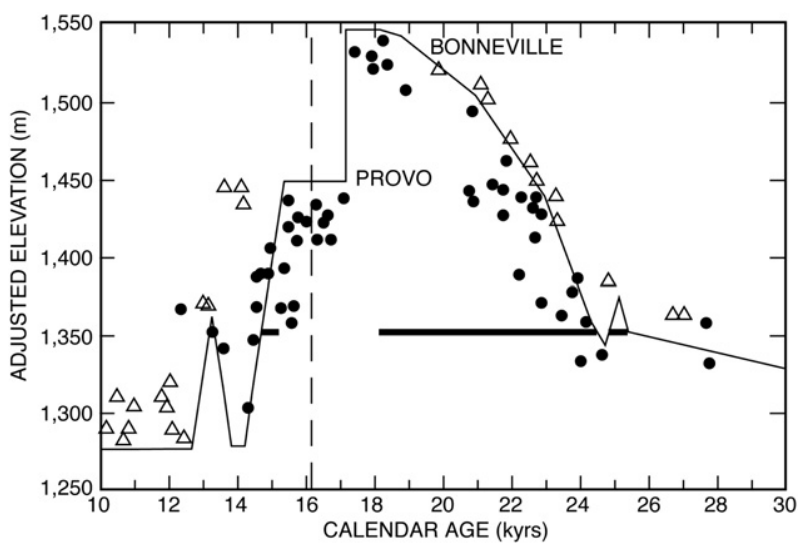

Fig. 5. Elevation versus time (in calendar years) for Lake Bonneville. The circles are for radiocarbon measurements on tufa or shells formed within the lake. The triangles are for radiocarbon measurements for terrestrial plants grown above the lake surface (Oviatt et al., 1992). The light line is a reconstruction of the lake-level history based on these radiocarbon measurements. The sharp drop, close to $17 \mathrm{ka}$, represents the down cutting from the Bonneville to the Provo level. The three segments of the heavy horizontal line represent times when $\mathrm{CaCO}_{3}$ was deposited in wave cut Cathedral Cave (McGee et al., 2012). Note that there seems to be no evidence for a lake-level change at $16.1 \mathrm{ka}$.

\section{Other terrestrial records}

Bolivia's Altiplano is a closed basin. Today it has two lakes, large Titicaca in the north and small Poopo in the south. Tufa-coated abandoned shorelines surrounding the dry solars to the south of Lake Poopo were formed in Lake Tauca which was several times larger than today's Titicaca. As documented by both ${ }^{14} \mathrm{C}$ and ${ }^{230} \mathrm{Th}$ ages, this lake was present from about 16.3 ka to about 14.4 ka (see Fig. 6). Prior to 16.3 ka only small and shallow lakes were present. Based on stratigraphic evidence, Placzek et al. (2006) conclude that a shallow LGM-age lake (Sajsi) largely dried up before the creation of large and deep Lake Tauca. If correct, then this desiccation may correspond to Estancia's Big Dry. But again, no convincing documentation has been reported.

Complementing the record for Bolivia's Altiplano is that from a sediment core in the Cariaco Basin. As shown in Fig. 7, abrupt changes in reflectance occur at about $16.3 \mathrm{ka}$ and at about $14.6 \mathrm{ka}$. As interpreted by Peterson et al. (2000), the lower the reflectance, the greater the input of river-born debris. If so, then the high reflectance interval between 16.3 and 14.6 ka represents a time of reduced debris input from Venezuelan rivers. This is consistent with a southward shift in the location of the Amazonian rain belt. It can also be seen that during the time interval prior to $16.3 \mathrm{ka}$ the reflectance was lower, suggesting a greater input of debris from rivers and hence wetter conditions in the northern part of Venezuela during the first half of the Mystery Interval.

Edwards' group in Minnesota has obtained a highly precisely ${ }^{230} \mathrm{Th}$-dated ${ }^{18} \mathrm{O}$ record for stalagmites from China's Hulu cave (Wang et al., 2001). It has a pronounced 20-ka cycle which tracks Northern Hemisphere summer insolation. Times of stronger summer insolation are characterized by isotopically light calcite and times of weaker summer insolation by isotopically heavy calcite. This cycle is attributed to a greater contribution of isotopically light monsoon rainfall during warmer than average summers. These records also show millennial shifts corresponding to Heinrich and Dansgaard-Oeschger events. As shown in Fig. 8, there is a pronounced shift toward heavy oxygen at 16.1 ka suggesting that China's monsoons were stronger during the first half of the Mystery Interval than during the second half.

The designation 'Mystery Interval' was created because of the uncertainties in the cause for the 15 percent decline in the ${ }^{14} \mathrm{C}$ to $\mathrm{C}$ ratio in atmospheric $\mathrm{CO}_{2}$ and upper ocean $\sum \mathrm{CO}_{2}$ between 17.8 and $14.7 \mathrm{ka}$ (Broecker, 2009). As mentioned above, this decline has been beautifully verified by ${ }^{14} \mathrm{C}$ and ${ }^{230} \mathrm{Th}$ measurements on calcite from Hulu Cave. As can be seen in Fig. 3, the decline is linear. Almost all the points lie within the 2 sigma error of the ${ }^{14} \mathrm{C}$ ages (i.e., $0.08 \mathrm{ka}$ ) of this line. Clearly, no significant change in slope occurred at the time of the mid-Mystery Interval transition (i.e., $16.1 \mathrm{ka}$ ).

Finally, mountain glaciers in southern middle latitudes underwent recession beginning in the first half of the Mystery Interval. This glacier retreat has been well dated at Lago Argentino on the eastern flank of the Andes of southern South America. There, Strelin et al. (2011) showed that the large ice tongue that occupied Lago Argentino during the LGM had receded to a position well inside its Lateglacial moraines by as early as $\sim 16.4$ yrs ago. Glacier recession during the Mystery Interval also occurred on the other side of the South Pacific in the Southern Alps of New Zealand,

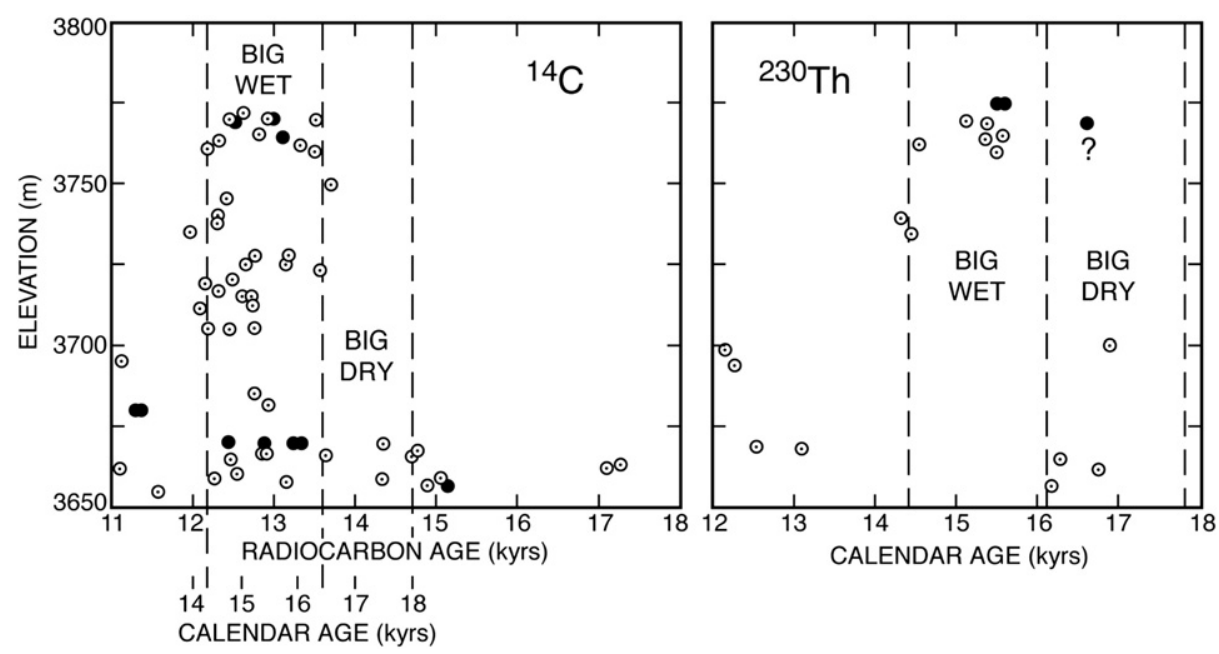

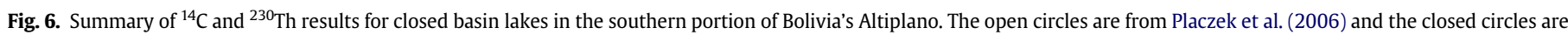

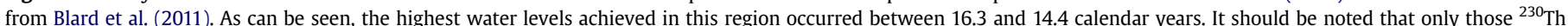

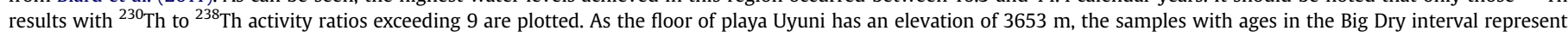
lakes with water depths no more than $15 \mathrm{~m}$. 


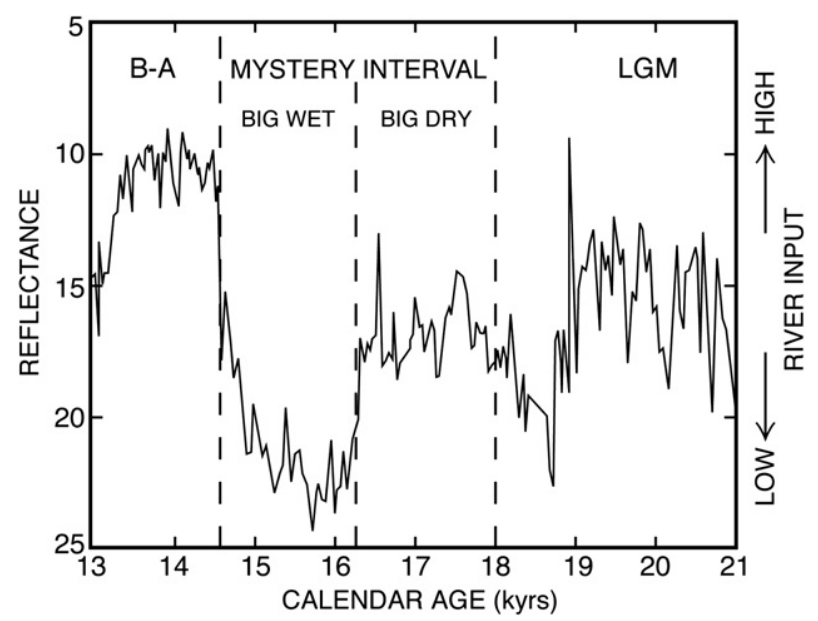

Fig. 7. Reflectance record for a core from the Cariaco Basin (in the Caribbean, north of Venezuela). It should be noted that the conversion of the ${ }^{14} \mathrm{C}$-based chronology to calendar years is not based on the Hulu calibration (Peterson et al., 2000). This record indicates that during the Big Wet, the delivery of river-born material was unusually low. The southward shift in the Amazonian rain belt dried out northern Venezuela.

where a ${ }^{10} \mathrm{Be}$ surface-exposure chronology of moraines nearby Lake Pukaki places the onset of deglaciation at $\sim 18.0$ yrs ago, i.e., at the beginning of the Mystery Interval (Schaefer et al., 2006; Putnam et al., 2010a,b). By the time of the Antarctic Cold Reversal, the glacier tongue in the Pukaki valley had retreated by more than one half of its full-glacial length (Putnam et al., 2010b). However, it remains unclear from available data whether glaciers in southern mid-latitudes registered a prominent switch at the transition from the first to the second half of the Mystery Interval, or if recession occurred at a constant rate throughout the entire interval. This remains an important question of Southern Hemisphere paleoclimatology.

\section{Ice core records}

In Fig. 9, the oxygen isotope record for atmospheric $\mathrm{O}_{2}$ trapped in polar ice (Severinghaus et al., 2009) is compared with that in Chinese stalagmites (Wang et al., 2001). As can be seen, the fluctuations in the two records match beautifully. This suggests that monsoons across the Northern Hemisphere weaken and strengthen in synchrony and, in so doing, imprint the isotopic composition of atmospheric $\mathrm{O}_{2}$. This is perhaps the strongest evidence in support of the global scope of the twofold Mystery Interval.

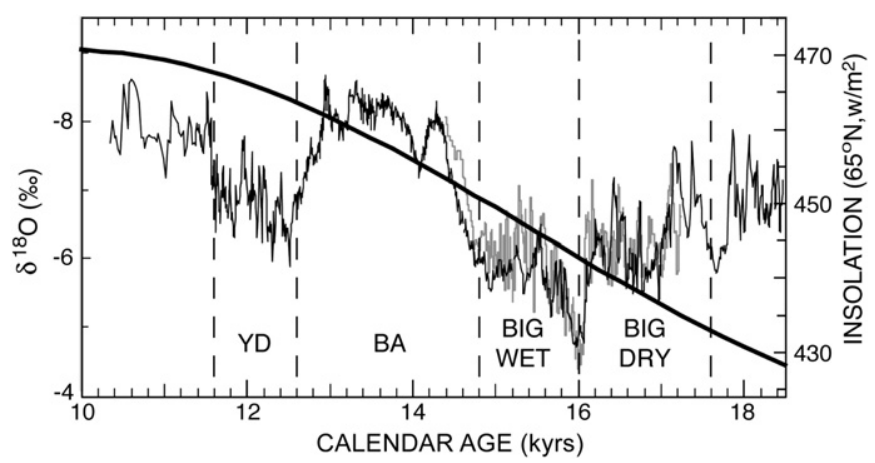

Fig. 8. The portion of the ${ }^{18} \mathrm{O}$ record in stalagmites from China's Hulu Cave which covers the deglacial time interval. Shown by the solid curve is the summer insolation at $65^{\circ} \mathrm{N}$. Note that during the time of the Big Wet, the monsoons are weaker and during the time of the Big Dry are stronger than expected from the magnitude of the summer insolation (Wang et al., 2001).

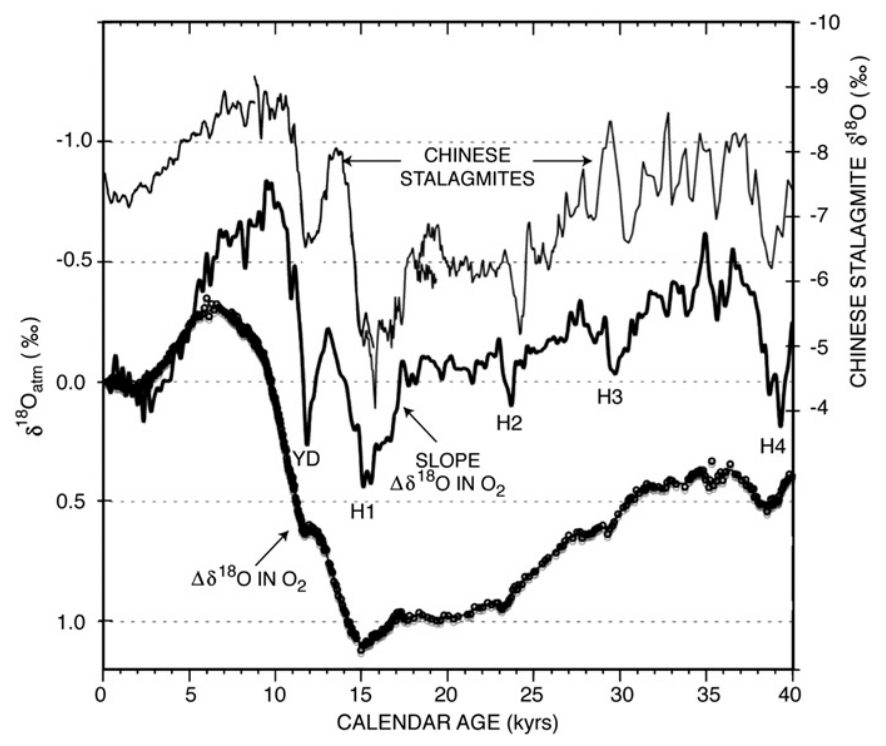

Fig. 9. Comparison of the ${ }^{18} \mathrm{O}$ record for atmospheric $\mathrm{O}_{2}$ (Severinghaus et al., 2009) with that of ${ }^{18} \mathrm{O}$ in Chinese stalagmites (Wang et al., 2001). The lower curve is that for the actual atmospheric $\mathrm{O}_{2}$ measurements and the middle curve, the deconvolved instantaneous composition of the $\mathrm{O}_{2}$ being produced. This deconvolution is necessary because the residence time of $\mathrm{O}_{2}$ in the atmosphere is about $1 \mathrm{ka}$. The similarity of the two isotopic records suggests that the Chinese monsoons are representative of the global monsoons. Note that the amplitude of the global signal is about one quarter of that for the Chinese stalagmites suggesting that monsoon vegetation accounts for about one quarter of the Earth's $\mathrm{O}_{2}$ production. The small offset of the time scales is not real but rather a deficiency in the ice-core chronology.

The ${ }^{18} \mathrm{O}$ to ${ }^{16} \mathrm{O}$ record in Antarctic ice has a two-stage Mystery Interval. As shown in Fig. 10, a steep post-LGM rise in $\delta^{18} \mathrm{O}$ begins at 17. $8 \mathrm{ka}$ and continues until $16.1 \mathrm{ka}$, at which time the rise flattens. This rise continues until $14.5 \mathrm{ka}$, at which time it dips into the Antarctic Cold Reversal.

Measurements on air trapped in Antarctic ice show that the atmosphere's $\mathrm{CO}_{2}$ content underwent a continuous rise during the course of the Mystery Interval. However, at $16.1 \mathrm{ka}$ a small upward jump occurs. It is followed by a decrease in slope (see Fig. 11).

The recently published ${ }^{13} \mathrm{C}$ record for $\mathrm{CO}_{2}$ trapped in polar ice (Schmitt et al., 2012) shows that during the first half of the Mystery Interval, the $\delta^{13} \mathrm{C}$ dropped by about $0.3 \%$. Then at about $16 \mathrm{ka}$, the slope changed and during the second half of the Mystery Interval, it

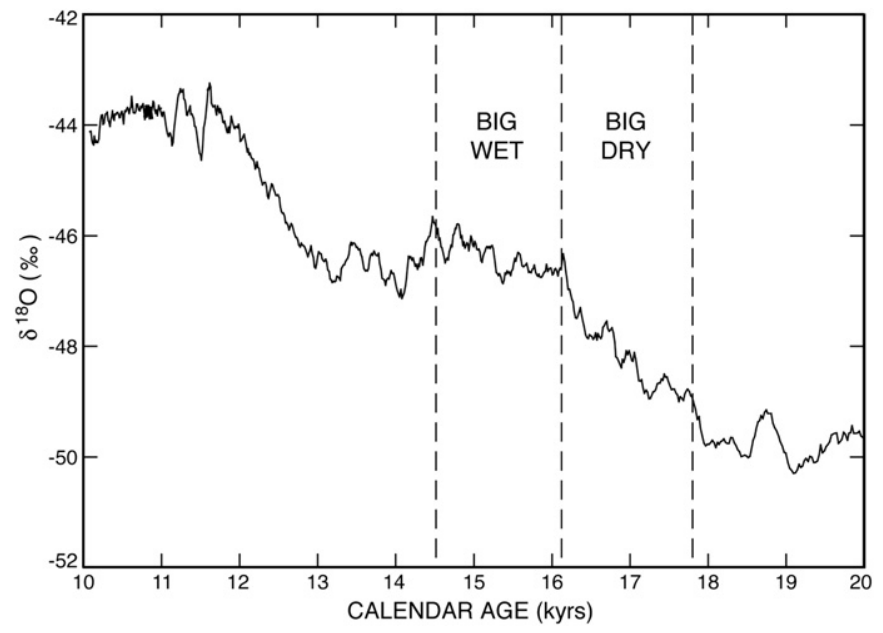

Fig. 10. Oxygen isotope record for Antarctic ice. As can be seen, the slope of the rise changes at about $16.1 \mathrm{ka}$. 


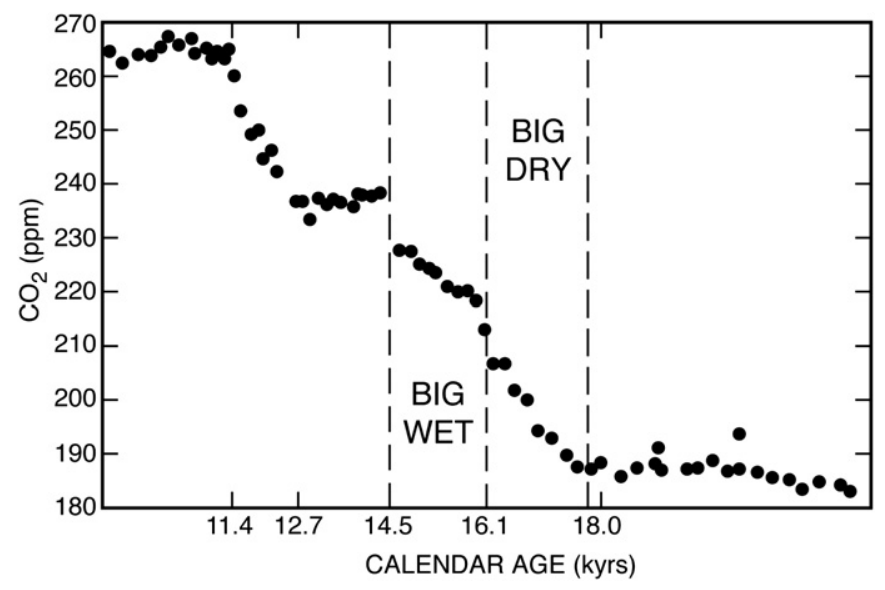

Fig. 11. $\mathrm{CO}_{2}$ record for bubbles trapped in Antarctic ice. As can be seen, a jump to higher values occurs at close to $16.1 \mathrm{ka}$. Also, the slope of this rise after $16.1 \mathrm{ka}$ is smaller than that before $16.1 \mathrm{ka}$.

underwent a small increase (see Fig. 12). Hence the slope of the ${ }^{13} \mathrm{C}$ record differs markedly from those for $\mathrm{CO}_{2}$ and for the ${ }^{14} \mathrm{C}$ to $\mathrm{C}$ ratio in atmospheric $\mathrm{CO}_{2}$. Both of the latter undergo unidirectional changes during the course of the Mystery Interval.

Schmitt et al. (2012) call on the release of ${ }^{13} \mathrm{C}$-deficient $\mathrm{CO}_{2}$ from the ocean to explain the $0.3 \%$ drop. But, as a pronounced change in slope occurs at $16 \mathrm{ka}$, it is difficult to come up with an oceanic explanation consistent with the $\mathrm{CO}_{2}$ and ${ }^{14} \mathrm{C}$ records (see Fig. 12). As shown by Broecker and McGee (submitted for publication), the dramatic slope change at about 16 ka corresponds to the end of a precipitous drop in the rain of dust onto the Antarctic ice cap (Röthlisberger et al., 2008) and also into the ocean off the southern coast of Australia (De Deckker et al., 2012). They suggest that the $0.3 \%$ drop in ${ }^{13} \mathrm{C}$ was the result of demise of iron fertilization in the Southern Ocean.

As reproduced in Fig. 13, the dust record in Greenland ice shows no change at the midpoint of the Mystery Interval. If McGee et al. (2010) are correct that dustiness is driven by gustiness and gustiness by the latitudinal temperature gradient, then, the very high calcium rain onto the Greenland ice cap through the entire course of the Mystery Interval requires the continued presence of extensive sea ice in the northern Atlantic. However, as already mentioned, the dust rain in Antarctica and the Southern Ocean comes to an end close to 16 ka ago (see Fig. 14). Further, unlike

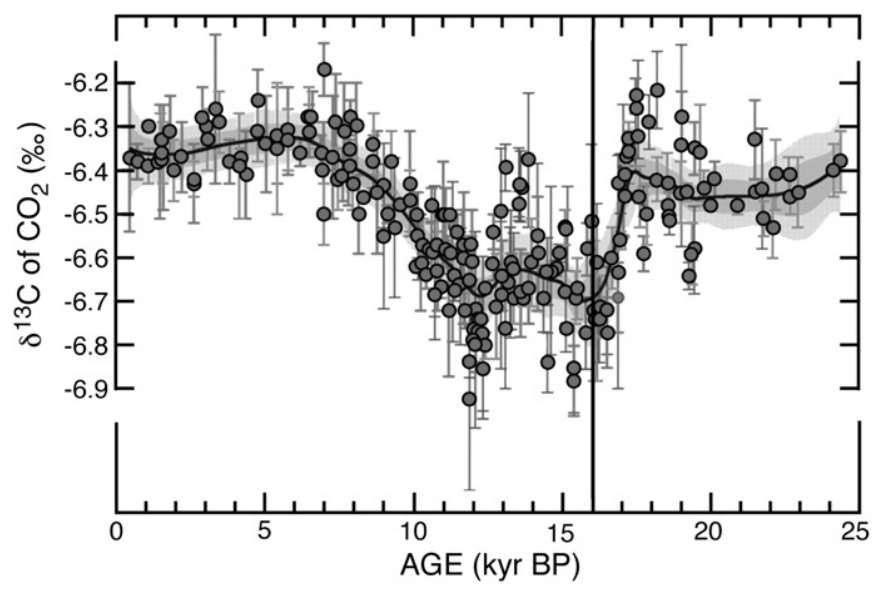

Fig. 12. The record for the $\delta^{13} \mathrm{C}$ in atmospheric $\mathrm{CO}_{2}$ trapped in polar ice for the last 25 ka (Schmitt et al., 2012).

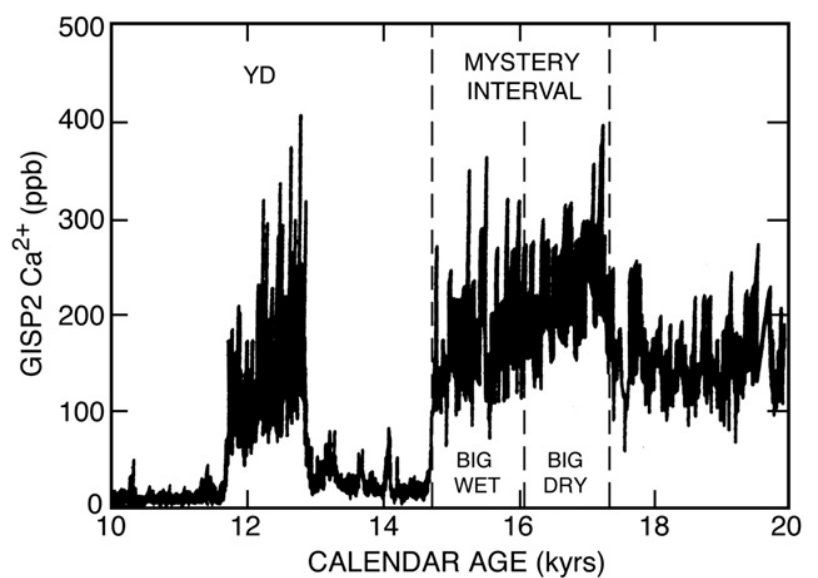

Fig. 13. A record for Greenland dust rain based on calcium concentrations in the ice (Mayewski et al., 1994). Note that no significant change occurs at $16.1 \mathrm{ka}$.

Greenland, there was no rejuvenation of the dust rain during the Younger Dryas.

\section{Ocean circulation record}

Based on the down-core measurements of the ratio of ${ }^{231} \mathrm{~Pa}$ to ${ }^{230} \mathrm{Th}$ in sediments northeast of Bermuda, McManus et al. (2004) make a case that during the entire Mystery Interval, the export of North Atlantic Deep Water largely shut down. They found no difference between the two parts of the Mystery Interval. So, this record can be added to that for the ${ }^{14} \mathrm{C}$ decline and for Greenland dust deposition as showing no break at $16.1 \mathrm{ka}$.

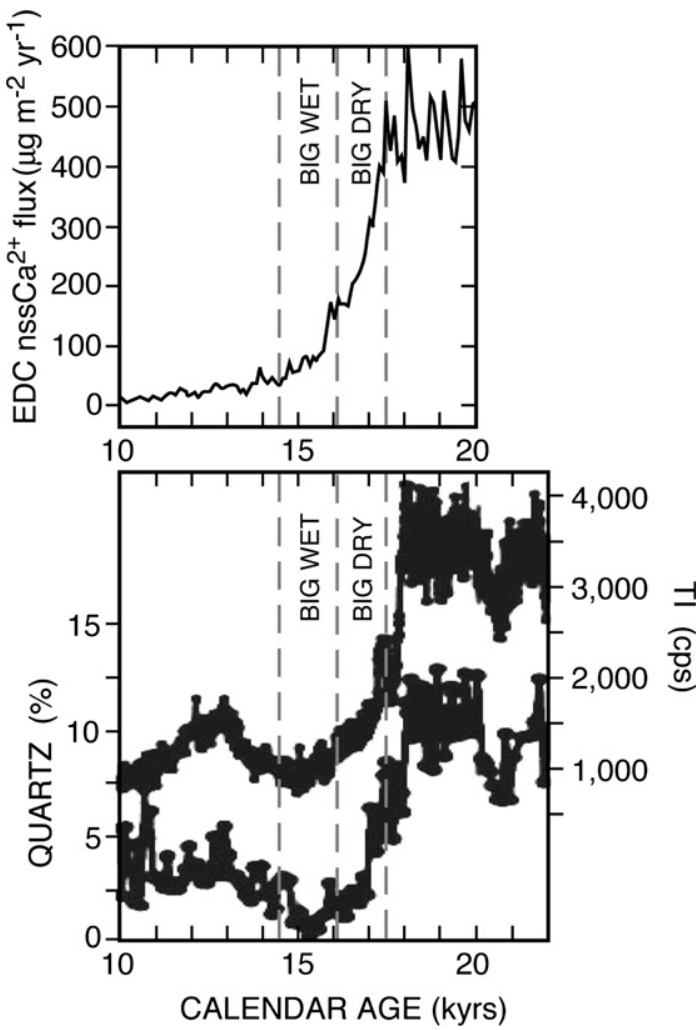

Fig. 14. Records of calcium rain onto the Antarctic ice cap (Röthlisberger et al., 2008) and of quartz and titanium onto the ocean just south of Australia (De Deckker et al., 2012). Both show sharp declines during the first half of the Mystery Interval. 


\section{Summary}

As summarized in Fig. 15, the most reliably dated of these records are those for ${ }^{18} \mathrm{O}$ in Chinese stalagmites and for $\mathrm{CO}_{2}$ and ${ }^{18} \mathrm{O}$ in Antarctic ice. They yield an age of close to $16.1 \mathrm{ka}$ for the mid Mystery Interval shift (see Figs. 8, 10 and 11). However, two of the other three records yield older ages (i.e., 16.9 ka for Estancia and $16.5 \mathrm{ka}$ for Lahontan). So the question arises as to whether these differences are real or whether they are the artifacts of errors in the ${ }^{14} \mathrm{C}$ ages. Although for Lahontan, it is possible that the near zero reservoir age has been underestimated, it is extremely unlikely that Estancia had a reservoir age of $0.8 \mathrm{ka}$. But it is possible that the samples included reworked ostracods. In the case of the Altiplano, the ${ }^{230} \mathrm{Th}$-based transition age could be as low as 16.1 if the outlying ${ }^{230} \mathrm{Th}$ age of $16.6 \mathrm{ka}$ is rejected. Three radiocarbon measurements on this same sample average $13.2{ }^{14} \mathrm{C}$ ka ( 15.9 calendar ka). A $0.2 \mathrm{ka}-$ reservoir correction would bring the age of this transition in line with those for the ${ }^{18} \mathrm{O}$ records in stalagmite, calcite and ice. Of course, the age differences may be real, in which case things are more complicated. In the following discussion, we opt for a single age of $16.1 \mathrm{ka}$ for all the records.

\section{What triggered the Big Dry to Big Wet change?}

It is generally agreed that the onset of the Mystery Interval was triggered by the H-1 armada of icebergs which, upon melting, capped the Northern Atlantic with a low salinity lid leading to a shutdown deep water formation. During the time interval when

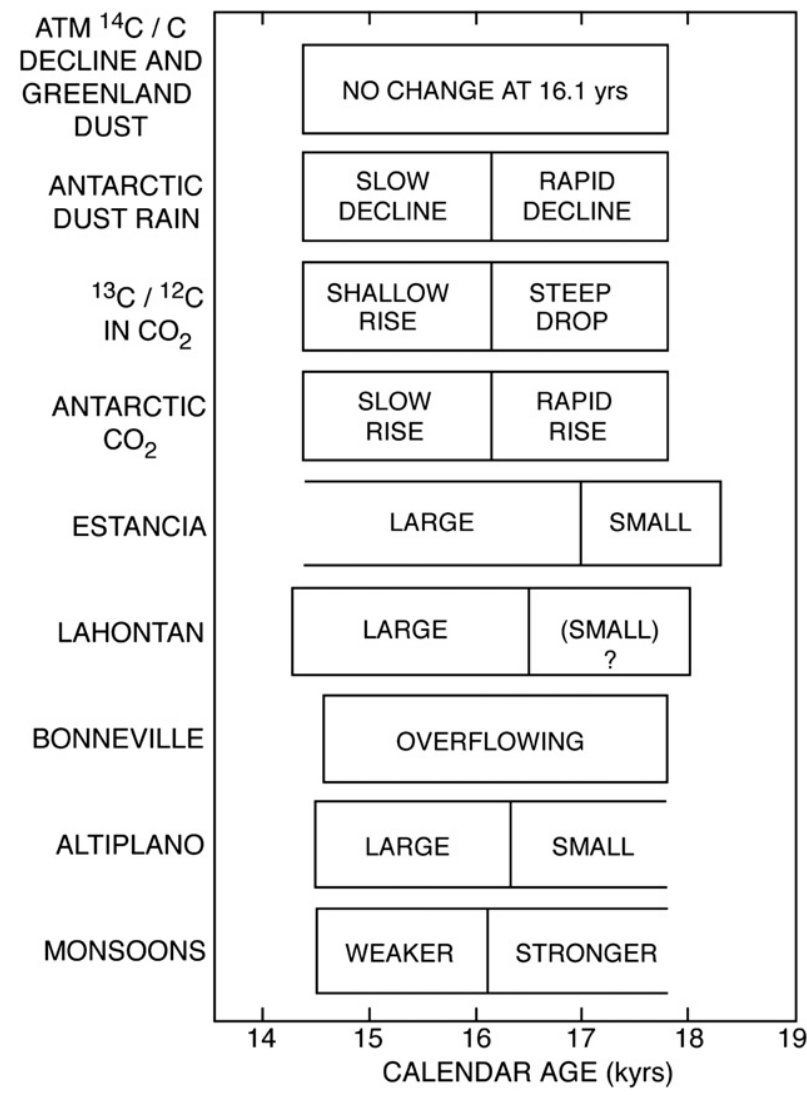

Fig. 15. Comparisons of nine Mystery Interval records. As can be seen, while there is good agreement regarding the timing of the end date, those for the Big Dry-Big Wet transition range over $0.9 \mathrm{ka}$. Of these, that of $16.1 \mathrm{ka}$ for the weakening of the Chinese monsoons and change in slope of the ice ${ }^{18} \mathrm{O}$ and $\mathrm{CO}_{2}$ records have by far the smallest uncertainty. Most anomalous is the 16.9-ka age for the dry to wet change in Estancia deep water production was suspended, a large expansion of sea ice cover in the northern Atlantic is thought to have occurred. The shutdown also appears to have had repercussions at the other end of the Atlantic which led to a reduction in sea ice extent around Antarctica (Anderson et al., 2009). As a result, the thermal equator underwent a southward shift carrying with it the tropical rain belt. Further, the steepening of the pole to equator temperature gradient in the Northern Hemisphere created by the expanded sea-ice increased gustiness and hence dustiness (McGee et al., 2010). The high dust rain persisted during the entire Mystery Interval.

The most reliable age for the $\mathrm{H}-1$ armada is that of $14.5{ }^{14} \mathrm{C} \mathrm{ka}$ obtained by Bard et al. (2000) for ice-rafted debris in a core from off the Iberian Peninsula. Based on the Southon et al. (2011) calibration, this translates to 17.6 calendar ka. This is broadly consistent with the radiocarbon-based age of $\mathrm{H}-1$ in the Atlantic's IRD belt. But for a number of reasons, this age has a large uncertainty (Hemming, 2004). The end of the Mystery Interval has been dated in many places by both ${ }^{14} \mathrm{C}$ and ${ }^{230} \mathrm{Th}$. The result is about 14.6 calendar years. These times bound prominent features of the marine record including: changes in the ratio of ${ }^{231} \mathrm{~Pa}$ to ${ }^{230} \mathrm{Th}$ in abyssal Atlantic sediments (McManus et al., 2004), a sharp drop in the ${ }^{14} \mathrm{C}$ to $\mathrm{C}$ ratio in benthic foraminifera in an intermediate-depth sediment off Baja California (Marchitto et al., 2007), and an increase in rate of opal deposition in the Southern Ocean (Anderson et al., 2009). As already mentioned, these dates also bound the first phase of the rise in the atmosphere's $\mathrm{CO}_{2}$ content (see Fig. 11) and the decline of the ${ }^{14} \mathrm{C}$ to $\mathrm{C}$ ratio in upper ocean $\sum \mathrm{CO}_{2}$ and atmospheric $\mathrm{CO}_{2}$ (see Fig. 3).

There is, however, evidence for second ice-rafting event. It comes from Bard et al.'s (2000) off-Iberia sediment core. It has a ${ }^{14} \mathrm{C}$ date of $13.7 \mathrm{ka}$ (i.e., 16.5 calendar ka), which places it close to the right time. The problem with the two-Heinrich event explanation is that, as mentioned above, the consequence of ice armadas is thought to bring about a freeze-over of the northern Atlantic pushing the thermal equator and its associated rain belts to the south. This appears to be the explanation for the increased wetness on the Altiplano and the weakening of the Northern Hemisphere monsoons. To make sense, it would have to be the second of Bard's ice armadas that shut down the deep water formation and allowed sea ice to form in the northern Atlantic. But, to initiate the reduction of the sea ice around Antarctica, the onsets of the ${ }^{14} \mathrm{C}$ decline, Anderson's opal maximum and the release of $\mathrm{CO}_{2}$ from the ocean and in the increased calcium rain onto Greenland, requires that the primary event was the onset of the Mystery Interval. If so, what happened at the midpoint of this interval?

We consider three possible scenarios to explain these observations. First, one possibility is that, as registered by Asian monsoons, southward migration of Earth's thermal equator, caused by sea-ice expansion in the North Atlantic, occurred steadily throughout the first part of the Mystery Interval and achieved its maximum southward displacement at $\sim 16.1 \mathrm{yrs}$ ago. This is consistent with marine records from the Southern Hemisphere (Anderson et al., 2009; De Deckker et al., 2012), and the rise of palaeolake Tauca, which began at $\sim 17.5$ yrs ago and achieved its maximum level by $\sim 16.0$ yrs ago (Blard et al., 2011). If correct, this would imply that, taken alone, IRD concentrations in North Atlantic sediments might not be directly indicative of overall sea-surface conditions, and hence the behavior of Earth's thermal equator. Improved chronologies documenting whether the signature of lake-level rise during the first half of the Mystery Interval in the Great Basin was abrupt or gradual could help to elucidate the cause of the transition at 16.0 yrs ago.

A second, complementary possibility is that lake levels in the American southwest were driven by a combination of global temperature gradients and local modification due to the orographic influence of Laurentide Ice Sheet on the subtropical jet (Benson et al., 1990). In this case, local influences of the Laurentide Ice 
Sheet on the jet stream must have been transmitted globally in order to explain climate switches occurring at $\sim 16,000$ yrs ago elsewhere across the planet.

Finally, a third possibility is that something happened in the Southern Ocean which further reduced its sea ice cover. Such a change would not significantly impact the pole to equator temperature gradient in the Northern Hemisphere (and hence the magnitude of the dust rain in Greenland), but it would give the thermal equator an additional push to the south and also change the location of the westerly wind belts. This idea is supported by the results on the core from Australia (De Deckker et al., 2012). Not only does it record an abrupt drop in dust rain between 17.5 and 16.0 ka but also a concurrent large warming of the surface ocean. In any case, something very important must have occurred in the Southern Ocean.

\section{Conclusions}

Estancia's Big Dry-Big Wet alternation appears to be part of a global hydrologic reorganization. It shows up in the ice core records for $\mathrm{CO}_{2}$, for the ${ }^{13} \mathrm{C}$ to ${ }^{12} \mathrm{C}$ ratio in the $\mathrm{CO}_{2}$ and for the ${ }^{18} \mathrm{O}$ to ${ }^{16} \mathrm{O}$ ratio in both ice and trapped $\mathrm{O}_{2}$. It is prominent in the ${ }^{18} \mathrm{O}$ record in Chinese stalagmites. In these records, the time for the transition is firmly fixed at $16.1 \mathrm{ka}$. Except for Estancia, there is no direct confirmation of the existence of a Big Dry in other Great Basin closed lakes. However, during the Big Wet, lakes in the Great Basin achieved their largest Late Quaternary size. The exception is Lake Bonneville, but its record is complicated by its overflow and the major down cutting of its outlet.

The absence of any change in rate of dust fall in Greenland and in ${ }^{231} \mathrm{~Pa}$ to ${ }^{230} \mathrm{Th}$ in the North Atlantic suggests that the extent of sea ice cover in the northern Atlantic underwent no significant change at $16.1 \mathrm{ka}$. Further, the absence of any change in the rate of Mystery Interval ${ }^{14} \mathrm{C}$ to $\mathrm{C}$ drop at $16.1 \mathrm{ka}$ is hard to explain if a change in ocean circulation is to be invoked. But the changes in lake size and in monsoon strength at $16.1 \mathrm{ka}$ appear to require a major southward shift of the thermal equator. Such a shift is thought to result from an expansion of sea ice cover in the northern Atlantic and hence an ice armada or melt-water flood. However, another possibility is that at 16.1 ka some change occurred in the Southern Ocean which led to a reduction in sea ice causing a second push to the south of the thermal equator.

Although the answer is not yet clear, any explanation for the operation of Earth's climate during the Last Glacial termination must account for the observed global hydrological switch that occurred midway through the Mystery Interval. A step toward understanding what the $16.1 \mathrm{ka}$ transition is trying to tell us requires precise chronologies. More accurate and precise chronologies of hydrological change in all of Earth's drylands are essential for tracking the response of Earth's thermal equator to conditions in the polar oceans. It is also important to nail down the precise age of the Heinrich \#1 ice armada. As foraminifera in the debris layers are extremely rare, the dates come from sediment just below and just above the layer itself. Even with these in hand, questions regarding the appropriate reservoir correction remain. Does the 16.1 ka event correspond to the second debris layer in Shackleton's Iberian core? Or does this point to a more complicated relationship between Heinrich IRD layers, sea-surface conditions, and the position of Earth's thermal equator?

\section{References}

Adams, K.D., Wesnousky, S.G., 1998. Shoreline processes and the age of the Lake Lahontan highstand in the Jessup embayment, Nevada. Geol. Soc. Am. Bull. 110, 1318-1332.
Allen, B.D., Anderson, R.Y., 2000. A continuous high-resolution record of late Pleistocene climate variability from the Estancia basin, New Mexico. Geol. Soc. Am. Bull. 112, 1444-1458.

Anderson, R.F., Ali, S., Bradtmiller, L.I., Nielsen, S.H.H., Fleisher, M.Q., Anderson, B.E., Burckle, L.H., 2009. Wind-driven upwelling in the Southern Ocean and the delacial rise in atmospheric $\mathrm{CO}_{2}$. Science 323, 1443-1448. http://dx.doi.org/10/ 1126/science.1167441.

Asmerom, Y., Pollyak, V.J., Burns, S.J., 2010. Variable winter moisture in the southwestern United States linked to rapid glacial climate shifts. Nat. Geosci.. http:// dx.doi.org/10.1038/NGEO754

Bard, E., Rostek, F., Turon, J.-L., Gendreau, S., 2000. Hydrological impact of Heinrich events in the subtropical northeast Atlantic. Science 289, 1321-1324.

Benson, L.V., Currey, D.R., Dorn, R.I., Lajoie, K.R., Oviatt, C.G., Robinson, S.W. Smith, G., Stine, S., 1990. Chronology of expansion and contraction of four Great Basin lake systems during the past 35,000 years. Palaeogeogr. Palaeoclim. Palaeoecol. 78, 241-286.

Blard, P.-H., Sylvestre, F., Tripati, A.D., Claude, C., Causse, C., Coudrain, A., Condom, T. Seidel, J.-L., Vimeux, F., Moreau, C., Dumoulin, J.-P., Lavé, J., 2011. Lake highstands on the Altiplano (Tropical Andes) contemporaneous with Heinrich 1 and the Younger Dryas: new insights from ${ }^{14} \mathrm{C}$, U-Th dating and $\delta^{18} \mathrm{O}$ of carbonates. Quat. Sci. Rev. 30, 3973-3989.

Broecker, W.S., 2009. The mysterious ${ }^{14} \mathrm{C}$ decline. Radiocarbon 51 (1), 109-119. The 50th Anniversary.

Broecker, W. Water sustainability in a warming world: a paleo-perspective. In: Water Sustainability and Quality, Elsevier Press, in press.

Broecker, W.S., McGee, D. The ${ }^{13} \mathrm{C}$ record for atmospheric $\mathrm{CO}_{2}$ : what is it trying to tell us? Earth Planet. Sci. Lett., submitted for publication.

Broecker, W.S., Walton, A.F., 1959. The geochemistry of C 14 in fresh-water systems. Geochim. Cosmochim. Acta 16 (1-3), 15-38.

Broecker, W.S., McGee, D., Adams, K., Cheng, H., Edwards, R.L., Oviatt, C.G., Quade, J., 2009. A Great Basin-wide dry episode during the first half of the mystery interval? Quat. Sci. Rev. 28, 2557-2563.

De Deckker, P., Moros, M., Perner, K., Jansen, E., 2012. Influence of the tropics and southern westerlies on glacial interhemispheric asymmetry. Nat. Geosci. 5, 266. http://dx.doi.org/10.1038/NGEO1431.

Garcia, A.F., Stokes, M., 2006. Late Pleistocene highstand and recession of a small, high-altitude pluvial lake, Jakes Valley, central Great Basin, USA. Quat. Res. 65, 179-186.

Hemming, S.R., 2004. Heinrich events: massive late pleistocene detritus layers of the North Atlantic and their global climate imprint. Rev. Geophys. 42 (1)

Lillquist, K.D., 1994. Late Quaternary Lake Franklin: lacustrine chronology, coastal geomorphology, and hydrostatic deflection in Ruby Valley and northern Butte Valley, Nevada. PhD thesis, University of Utah, Salt Lake City, Utah, 628 pp.

Marchitto, T.M., Lehman, S.J., Ortiz, J.D., Flückiger, J., van Geen, A., 2007. Marine radiocarbon evidence for the mechanism of deglacial atmospheric $\mathrm{CO}_{2}$ rise Science 316, 1456-1459. http://dx.doi.org/10.1126/science.1138679.

Mayewski, P.A., Meeker, L.D., Whitlow, S., Twickler, M.S., Morrison, M.C. Bloomfield, P., Bond, G.C., Alley, R.B., Gow, A.J., Meese, D.A., Grootes, P.M. Ram, M., Taylor, K.C., Wemkes, W., 1994. Changes in atmospheric circulation and ocean ice cover over the North Atlantic during the last 41,000 years. Science 263, 1747-1751. http://dx.doi.org/10.1126/science.263.5154.1747.

McGee, D., Broecker, W.S., Winckler, G., 2010. Gustiness: the driver of glacial dustiness? Quat. Sci. Rev. 29, 2340-2350. http://dx.doi.org/10.1016/j.quascirev.2010.06.009.

McGee, D., Quade, J., Edwards, R.L., Broecker, W.S., Cheng, H., Reiners, P.W., Evenson, N. 15 October, 2012. Lacustrine cave carbonates: novel archives of paleohydrologic change in the Bonneville Basin (Utah., USA). Earth Planet. Sci. Lett. 351/352, 182-194.

McManus, J.F., Francois, R., Gherardi, J.-M., Keigwin, L.D., Brown-Ledger, S., 2004 Collapse and rapid resumption of Atlantic meridional circulation linked to deglacial climate changes. Nature 428, 834-837.

Oviatt, C.G., Currey, D.R., Sack, D., 1992. Radiocarbon chronology of Lake Bonneville, Eastern Great Basin, USA. Palaeogeogr. Palaeoclim. Palaeoecol. 99, 225-241.

Peterson, L.C., Haug, G.H., Hughen, K.A., Röhl, 2000. Rapid changes in the hydrologic cycle of the tropical Atlantic during the Last Glacial. Science 290, 1947-1950.

Placzek, C., Quade, J., Patchett, P.J., 2006. Geochronology and stratigraphy of late Pleistocene lake cycles on the southern Bolivian Altiplano: implications for causes of tropical climate change. Geol. Soc. Am. Bull. 118, 515-532. http:// dx.doi.org/10.1130/B25775.1.

Putnam, A.E., Schaefer, J.M., Barrell, D.J.A., Vandergoes, M., Denton, G.H., Kaplan, M.R., Finkel, R.C., Schwartz, R., Goehring, B.M., Kelley, S.E., 2010a. In situ cosmogenic ${ }^{10}$ Be production-rate calibration from the Southern Alps, New Zealand. Quat. Geochronol. 5, 392-409.

Putnam, A.E., Denton, G.H., Schaefer, J.M., Barrell, D.J.A., Andersen, B.G., Finkel, R.C., Schwartz, R., Doughty, A.M., Kaplan, M.R., Schlüchter, C., 2010b. Glacier advance in southern middle-latitudes during the Antarctic cold reversal. Nat. Geosci. 3, 700-704.

Redwine, J.L., 2003. Quaternary pluvial history and paleoclimatic implications of Newark Valley, east-central Nevada. M.S. thesis, Humboldt State Univ. Arcata, California, 358 pp.

Röthlisberger, R., Mudelsee, M., Bigler, M., de Andelis, M., Fischer, H., Hansson, M., Lambert, F., Masson-Delmotte, V., Sime, L., Udisti, R., Wolff, E.W., 2008. The Southern Hemisphere at glacial terminations: insights from the Dome $C$ ice core. Clim. Past 4, 345-356.

Severinghaus, J.P., Beaudette, R., Headly, M.A., Taylor, K., Brook, E.J., 2009. Oxygen-18 of $\mathrm{O}_{2}$ records the impact of abrupt climate change on the terrestrial biosphere. Science 324, 1431-1434. 
Schaefer, J.M., Denton, G.H., Barrell, D.J.A., Ivy-Ochs, S., Kubik, P.W., Andersen, B.G., Phillips, F.M., Lowell, T.V., Schlüchter, C., 2006. Near-synchronous interhemispheric termination of the last glacial maximum in mid-latitudes. Science 312, 1510-1513.

Schmitt, J., Schneider, R., Elsig, J., Leuenberger, D., Lourantou, A., Chappellaz, J. Köhler, F., Joos, Stocker, T.F., Leuenberger, M., Fischer, H., Mar 29, 2012. Carbon isotope constraints on the deglacial $\mathrm{CO}_{2}$ rise from ice cores. Science, 1. http:// dx.doi.org/10.1126/science.1217161.

Southon, J., Noronha, A.L., Cheng, H., Edwards, R.L., Wang, Y., December 21, 2011. A high-resolution record of atmospheric ${ }^{14} \mathrm{C}$ based on Hulu Cave speleothem H82. J. Quat. Sci. Rev.. http://dx.doi.org/10.1016/j.quascirev.2011.11.022
Strelin, J.A., Denton, G.H., Vandergoes, M.J., Ninnemann, U.S., Putnam, A.E., 2011. Radiocarbon chronology of the late-glacial Puerto Bandera moraines, Southern Patagonian Icefield, Argentina. Quat. Sci. Rev. 30, 2551-2569.

Tackman, G.E., 1993. Pleistocene hydrologic history of Diamond Valley, Nevada, with climatic and isostatic implications. M.S. thesis, University of Utah, Salt Lake City, Utah, 192 pp.

Wang, Y.J., Cheng, H., Edwards, R.L., An, Z.S., Wu, J.Y., Shen, C.-C., Dorale, J.A., 2001. A high-resolution absolute-dated last Pleistocene monsoon record from Hulu Cave, China. Science 294, 2345-2348.

Wanninkhof, R., Ledwell, J.R., Broecker, W.S., 1985. Gas exchange wind speed relation measured with sulfur hexafluoride on a lake. Science 227, 1224-1226. 